\title{
CHANGES IN THE ELECTROCARDIOGRAM DURING INDUCTION OF ANAESTHESIA AND ENDOTRACHEAL INTUBATION
}

\author{
Marvin J. Noble and Wiluiam S. Derrick, M.D. ${ }^{1}$
}

EARLIER STUDIES on electrocardiogram changes during induction of anaesthesia and endotracheal intubation have pointed up the possibility of a vago-vagal reflex as the source of cardiac arrhythmias Reid and Brace (1) demonstrated cardiac acceleration resulting from stimulation of respiratory mucosa during endotracheal intubation. More recently, reduction in the number of arrhythmias and tachycardias has been accomplished by changing the anaesthetic used in order to block this reflex arc $(2,3,4)$. In another study, Denson and Joseph $(5)$ showed that adequate-ventilation of the patient prior to intubation would prevent the development of cardiac arrhythmias. It has also been demonstrated that a minimal level of anaesthesia during laryngoscopy and endotracheal intubation predisposes the patient to a rise in blood pressure and tachycardia (6).

\section{METHODS}

The patients included in this study were premedıcated with pentobarbital, meperidine, promethazıne, and scopolamine. Anaesthesia induction consisted of sufficient thiopentone, intravenously, to put the patient to sleep, followed by nitrous oxide, ether, oxygen, hyperventilation, and finally endotracheal intubation In most cases, 4 to $9 \mathrm{mg}$ of d-tubocurarine were administered intravenously about $5 \mathrm{~mm}$. before intubation. There was one case of a ten-month old unfant who was induced with cyclopropane, nitrous oxide, oxygen, and then mantained on cyclopropane, nitrous oxide, ether, and oxygen mixture without intubatıng The three other exceptions to the method above were an elderly tracheostomized patient, one who received the above anaesthesia but was not intubated and one who recelved thiopentone, nitrous oxıde, and succinylcholine.

Except for two patıents on whom lead I was used, patients were monitored via lead II using a Sariborn Model 51 Viso Cardiette direct-writing electrocardiograph. Tracings were taken before induction, at various stages of induction, during laryngoscopy and intubation, and at brief intervals shortly following intubation

\section{RESULts}

A total of 80 inductions were followed Eighteęn patients developed arrhythmias Changes in the height of the $\mathrm{P}, \mathrm{QRS}$, and T waves were noted. Depression of the S-T segment, prolongation of the P-R and QRS intervals, and notching or slurring of the QRS complex were also observed. A summary of these findings and the time relationshp in respect to intubation is found in Table $I$.

1The University of Texas, M. D. Anderson Hospital and Tumor Institute, Houston, Texas. 
The types of arrhythmia included premature ventricular and premature auricular systoles, A-V nodal rhythm, interference 'dissociation, and sinus arrhythmia. Changes in the $\mathrm{P}$ and $\mathrm{T}$ waves were mainly small height changes but in a few instances, the wave disappeared. The miscellaneous changes classified in Table I as "Others" include notching and wave duration changes. There may have been more than one change in a wave during the induction. but only the first change is considered in Table I.

\section{TABLE I}

Changes in the ECG dúring Induction and Intubation

\begin{tabular}{lcccc}
\hline & \multicolumn{3}{c}{ Time with respect to intubation } & \\
\cline { 2 - 4 } \multicolumn{1}{c}{ Change } & Before & During & After & Total \\
\hline Arrhythmia & 11 & 6 & 1 & 18 \\
P-wave height & 29 & 3 & 0 & 32 \\
QRS height & 7 & 7 & 3 & 17 \\
T-wave height & 23 & 4 & 2 & 29 \\
S-T depression & 2 & 2 & 1 & 5 \\
Others & 2 & 6 & 0 & 8 \\
\hline
\end{tabular}

Tachycardia was defined in a relative sense for the purpose of this study as an increase in the heart rate of at least 22 beats per minute The period of change in rate to be observed was arbitrarily selected to begin with laryngoscopy and to end 3 minutes after intubation. In 78 intubations, there were 39 relative tachycardias produced. There were two cases of relative bradycardia.

It was noted that the ECG tracing taken in the operating room after premedication but before anaesthesia did not always correspond to that taken before premedication.

\section{Discussion}

The significance of changes in depolarization and repolarization voltages in the myocardium during induction of anaesthesia is not clearly known. Lepeshkin (7) has shown that cold fluids given intravenously will affect the $T$ wave. It is notable that most changes in the present study occurred before laryngoscopy and endotracheal intubation Only the changes in the QRS height and the S-T depressions were equal in number before and during endotracheal intubation. There were some changes in wave height after intubation, but these were secondary changes and are therefore not listed in Table I. The time relation of these changes, especially the arrhythmias, would indicate a role being played by the premedicating drugs and/or the anaesthetics used for induction. This role has not been fully described.

The great number of relative tachycardias seen on intubation ( 50 per cent) is in keeping with earlier findings $(1,2,3,4)$. Here again, timing is relevant as the greatest rate occurred about $1 \frac{1}{2}$ to 2 minutes after intubation. This time was 
usually $1 / 2$ to 1 minute after the cuff on the endotracheal tube was inflated. This result indicates greater stimulation from cuff inflation than from intubation perse

\section{Conclusions and Summary}

The stumulation of respiratory epithelium seemingly plays a large role in causing a relative tachycardia and, in addition, the role of the premedication drugs and the anaesthetics used is of increasing interest as the source of preendotracheal intubation ECG changes.

Eighty patients were followed through induction of anaesthesia and endotracheal intubation with lead II electrocardıgrams. Changes in wave voltą,e, rate, and rhythm were observed The heart rate increased in 50 per cent of the patients upon intubation. Approximately 60 per cent of other electrocarliogram changes occurred before laryngoscopy and endotracheal intubation.

\section{ACKNOWLEDGMENT}

We are indebted to Miss Joyce E. Nichols for technical assistance in electrocardiography.

\section{RÉSUMÉ}

Chez 80 malades, nous avons fait un tracé électrocardiographique en deuxième dérivation au cours de l'induction de l'anesthésie et de l'intubation endotrachéale. Nous avons observé des modifications dans le voltage, la vitesse et le rythme. Les malades que nous avons étudiés avaient reçu coname prémédication: du pentobarbital, de la mépéridine, de la promethazine et de la scopolamine. Nous avons 'fait l'induction de l'anesthésie en donnant du thiopentone en quantité suffisante pour obtenur du sommeil et nous avons continué avec du protoxide d'azote, de l'éther, de l'oxygène, de l'hyperventilation et ensuite nous avons pratiqué l'intubation endotrachéale. Dans la plupart des cas, nous avons donné, par voie endoveineuse, de 4 à $9 \mathrm{mg}$ de d-tubocurarine environ cinq minutes avant l'intubation.

Au moment de l'intubation, dans 50 pour cent des cas, le cœur s'est accéléré. Nous avons observé des changements dans le voltage, la vitesse et le rythme et, dans environ 60 pour cent des cas, ces changẹments électrocardiographiques sont apparus avant la laryngoscopie et l'intubation endotrachéale. A ce sujet, il est intéressant d'étudier le rôle des médicaments employés en prémédication et comme agents anesthésiques.

\section{REFERENCES}

1. Rem, L C, \& Brace, D E Inrtation of Respiratory Tract and Its Reflex Effect upon Heart. Surg, Gynec. \& Obst. 70157 (Feb, 1940)

2. Burstetn, Charles L., Lo Pinto, F J., \& Newman, W Electrocardiographic Studies during Endotracheal Intubation Effects durng Usual Rouline Technics. Anesthesiology 11. 224 (March, 1950). 
3 Arcuri, R A, Newman, W., \& Burstein, C L Electrccardiographic Studies during Endotracheal Intubation Effects durng General Anesthesia and Hexylcaine Hydrochlonde Topical Spray Anesthesiology 1446 ( Jan, 1953).

4 Dance, C L, Jr Electrocardıographic Studıes durıng Endotracheal Intubatıon Evipal Sodium Induction Anesthesiology 17730 (Sept-Oct, 1956).

5 Denson, J S, \& Joseph, S I Cardiac Rhythm and Endotracheal Intubation Anesthesiology 15650 (Nov, 1954)

6 Dripps, R D \& Vandam, L D Anesthetic Management of Patients with Heart Disease. Crrculation 5927 (June, 1952).

7 Lepeschin, E Distortion of Electrocardiographic Effect; of Intravenously Injected Solutions due to Cooling of Myocardium Am J Pliysiol 169400 (May, 1952) 